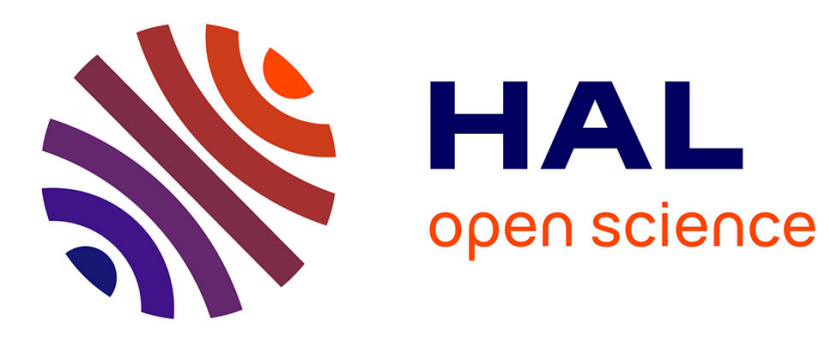

\title{
Interaction of fluorescently labeled pyrrole-imidazole polyamide probes with fixed and living murine and human cells
}

Karine Nozeret, François Loll, Gildas Mouta-Cardoso, Christophe Escude, Alexandre S Boutorine

\section{To cite this version:}

Karine Nozeret, François Loll, Gildas Mouta-Cardoso, Christophe Escude, Alexandre S Boutorine. Interaction of fluorescently labeled pyrrole-imidazole polyamide probes with fixed and living murine and human cells. Biochimie, 2018, 10.1016/j.biochi.2018.03.008 . hal-02382490

\section{HAL Id: hal-02382490 \\ https://hal.science/hal-02382490}

Submitted on 2 Dec 2019

HAL is a multi-disciplinary open access archive for the deposit and dissemination of scientific research documents, whether they are published or not. The documents may come from teaching and research institutions in France or abroad, or from public or private research centers.
L'archive ouverte pluridisciplinaire HAL, est destinée au dépôt et à la diffusion de documents scientifiques de niveau recherche, publiés ou non, émanant des établissements d'enseignement et de recherche français ou étrangers, des laboratoires publics ou privés. 


\section{Interaction of fluorescently labeled pyrrole-imidazole polyamide probes with fixed and living murine and human cells}

Gildas Mouta-Cardoso, Christophe Escude, Alexandre Escudé, Karine Nozeret, François Loll, Mouta Gildas, Christophe Cardoso, Alexandre

Boutorine

\section{To cite this version:}

Gildas Mouta-Cardoso, Christophe Escude, Alexandre Escudé, Karine Nozeret, François Loll, et al.. Interaction of fluorescently labeled pyrrole-imidazole polyamide probes with fixed and living murine and human cells. Biochimie, Elsevier, 2018, 10.1016/j.biochi.2018.03.008 . hal-02382490

\section{HAL Id: hal-02382490 \\ https://hal.archives-ouvertes.fr/hal-02382490}

Submitted on 2 Dec 2019

HAL is a multi-disciplinary open access archive for the deposit and dissemination of scientific research documents, whether they are published or not. The documents may come from teaching and research institutions in France or abroad, or from public or private research centers.
L'archive ouverte pluridisciplinaire HAL, est destinée au dépôt et à la diffusion de documents scientifiques de niveau recherche, publiés ou non, émanant des établissements d'enseignement et de recherche français ou étrangers, des laboratoires publics ou privés. 


\title{
Graphical Abstract
}

To create your abstract, type over the instructions in the template box below.

Fonts or abstract dimensions should not be changed or altered.

\author{
Interaction of fluorescently labeled pyrrole- \\ Leave this area blank for abstract info. \\ imidazole polyamide probes with fixed and \\ living murine and human cells \\ Karine Nozeret, François Loll, Gildas Mouta Cardoso, Christophe Escudé and Alexandre S. Boutorine \\ Muséum National d'Histoire Naturelle, CNRS UMR7196, INSERM U1154, 57 rue Cuvier, B.P. 26, 75231 Paris \\ cedex 05, France
}




\title{
Interaction of fluorescently labeled pyrrole-imidazole polyamide probes with fixed and living murine and human cells
}

\author{
Karine Nozeret ${ }^{1}$, François Loll, Gildas Mouta Cardoso, Christophe Escudé* and Alexandre S. Boutorine \\ Muséum National d'Histoire Naturelle, CNRS UMR7196, INSERM U1154, 57 rue Cuvier, B.P. 26, 75231 Paris cedex 05, France, \\ e-mails:karine.nozeret@gmail.com, floll@mnhn.fr, mouta@mnhn.fr, christophe.escude@mnhn.fr, alexandre.boutorine@mnhn.fr (*corresponding author). \\ ${ }^{1}$ Present address: Institut Pasteur, 25-28 rue du Docteur Roux, 75724 Paris Cedex 15, France
}

\section{ARTICLE INFO}

Article history:

Received

Received in revised form

Accepted

Available online

Keywords:

Pyrrole-Imidazole polyamides

Fluorescent probes

Repeated sequences

Human and murine centromeres

Living cells

DNA imaging

\section{ABSTRACT}

Pericentromeric heterochromatin plays important roles in controlling gene expression and cellular differentiation. Fluorescent pyrrole-imidazole polyamides targeting murine pericentromeric DNA (major satellites) can be used for the visualization of pericentromeric heterochromatin foci in live mouse cells. New derivatives targeting human repeated DNA sequences ( $\alpha$-satellites) were synthesized and their interaction with target DNA was characterized. The possibility to use major satellite and $\alpha$-satellite binding polyamides as tools for staining pericentromeric heterochromatin was further investigated in fixed and living mouse and human cells. The staining that was previously observed using the mouse model was further characterized and optimized, but remained limited regarding the fluorophores that can be used. The promising results regarding the staining in the mouse model could not be extended to the human model. Experiments performed in human cells showed chromosomal DNA staining without selectivity. Factors limiting the use of fluorescent polyamides, in particular probe aggregation in the cytoplasm, were investigated. Results are discussed with regards to structure and affinity of probes, density of target sites and chromatin accessibility in both models.

\section{Research highlights}

Fluorescent probes targeting human $\alpha$-satellite DNA sequences were synthesized.

In fixed mouse cells, probes targeting major satellite DNA stain heterochromatin foci.

- In living mouse cells, only certain probes were suitable for this staining.

In fixed and living human cells, non-specific labeling of the whole DNA was observed.

\section{Introduction}

The observation of the dynamics of a native double-stranded DNA in living cells by fluorescence microscopy is a serious challenge for cellular biology [1]. The FISH (Fluorescence in situ hybridization) method is based on the fixation of cells and the denaturation of DNA, thus it is incompatible with living cells [24]. Imaging of native DNA has been achieved using quite complicated methods as the incorporation of fluorescent nucleotides during DNA replication $[5,6]$ or the fusion of fluorescent proteins (such as GFP or similar) to endogenous DNA binding proteins [7-9]. The recent achievements in the live cell imaging are based on the use of two natural DNA recognition systems, the TALE motif $[10,11]$ and the CRISPR/Cas9 system
[12-14]. However, these approaches require transgenic techniques that can modify the genetic nature of the cells.

Recently, we have used fluorescently labeled synthetic Nmethylpyrrole-N-methylimidazole (Py-Im) polyamides that bind specifically to the minor groove of double-stranded DNA for imaging major satellite sequences, which form the basis of pericentromeric heterochromatin foci, in living mouse cells [15]. This approach does not necessitate genome modifications; the polyamides easily penetrate into the cells without toxicity and specifically recognize their target native dsDNAs. Fluorescent polyamide probes were synthesized, characterized and successfully applied for living cell imaging. However, several unexpected problems were discovered: i) fluorophore conjugation decreased polyamide affinity for DNA; ii) several fluorophores affected the nuclear penetration of the probes and iii) a quick fluorophore bleaching under the conditions of microscopic observation was revealed.

The present work aims at better understanding the different factors that affect the feasibility of this approach: DNA sequence, fluorophores, cell type, culture medium. We first designed, synthesized and characterized polyamide probes targeting pericentromeric repeats that are found in the human genome. Then we investigated, using mouse and human cells as models, how polyamide probes penetrate into cells and enable the labeling of pericentromeric heterochromatin foci. 


\section{Materials and methods}

\subsection{Materials and reagents}

Monomers for polyamide synthesis: 4-(Boc-amino)-1-methyl1H-pyrrole-2-carboxylic acid, 4-(Boc-amino)-1-methyl-1Himidazole-2-carboxylic acid, N-Boc- $\beta$-alanine and N-Boc- $\gamma$ aminobutyric acid were purchased from Bachem (Germany) and PolyPeptide Laboratories (France). Activating reagent HATU (2(1H-7-azabenzotriazol-1-yl)-1,1,3,3-tetramethyl uronium hexafluorophosphate) and HOAT (1-hydroxy-7-azabenzotriazole) were from "Molekula" (UK). Boc-ß-ala-Pam (Boc-ß-alanine-(4carbonylaminomethyl)-benzyl-ester-copoly-(styrene-divinyl-

benzene) resin was from Merck. N-Hydroxysuccinimide esters of fluorophores Cy3 (Cy3-NHS), Cy5 (Cy5-NHS), Oregon Green (OG-NHS), Rhodamine (Rh-NHS) and fluorescein-NHS, as well as fluorescein-5-isothiocyanate were from FluoProbes. Other reagents (salts, monomers and organics) were purchased from Sigma-Aldrich, Acros, Merck, Fluka and Fisher Scientific, and solvents from Carlo Erba. Target oligonucleotides for physicochemical studies and all the oligonucleotide probes were purchased from Eurogentec (Seraing, Belgium). DMEM High glucose Glutamax-supplemented and RPMI 1640 Glutamaxsupplemented culture media were from Gibco, fetal bovine serum - from Eurobio, imaging DMEMgfp medium from Euromedex, Denhart solution and Rutin - from Sigma-Aldrich, blocking reagent - from Roche.

Reverse-phase HPLC analysis and purification were performed on Agilent Technologies 1200 analytical and preparative chromatographs piloted by Agilent ChemStation software. Mass spectrometry analysis by electrospray Q-TOF (ESI Q-TOF MS) was performed on a Q-Star instrument (Applied Biosystems, Courtaboeuf, France) in the positive mode; analyses were performed in methanol. UV-Vis spectra and thermal denaturation curves were obtained on an Uvikon XL UV-visible spectrophotometer (Secomam, Nova Analytic Company) with 12 quartz cells installed in a mobile thermostated support piloted by ThermAlys software (DuDoTec GmbH). A thermostat Julabo F25, piloted by Easy Temp Professional software, was used to monitor the temperature. Polyacrylamide gels were scanned on a Typhoon 9410 (Amersham) fluorescence scanner with a laser excitation at $532 \mathrm{~nm}$ and an emission filter at $526 \mathrm{~nm}$. CD spectra were recorded on a Jasco J-810 spectropolarimeter. Fluorescence spectra were recorded on a SPEX Fluorolog II (Jobin-Yvon - Horiba) spectrofluorometer.

\subsection{Polyamide synthesis and characterization}

The synthesis of polyamides has been done according to the method by Krutzik and Chamberlin [16, 17] with several modifications [18]. The products were purified and characterized as it was described previously [18]. The interactions of each polyamide with their target DNA fragments have been studied by polyacrylamide gel electrophoresis using "gel retardation" method, by thermal denaturation of complexes "target duplex polyamide" and by circular dichroism spectroscopy.

\subsection{Synthesis of fluorophores bearing isothiocyanate groups}

Insertion of amino group. N-hydroxysuccinimide esters of the fluorophores (OG-NHS or Rh-NHS, $10 \mu$ moles) were dissolved in dry DMF $(50 \mu \mathrm{L})$. A solution of BOC-diaminopropane (40 $\mu$ moles $)$ in dry $\operatorname{DMF}(50 \mu \mathrm{L})$ and diisopropyle ethylamine (DIPEA, $15 \mu \mathrm{L}$ ) were added, well mixed and the mixture was incubated overnight at room temperature. The product was purified by preparative reversed-phase HPLC and the solvent evaporated. The BOC protection was removed by incubation with $20 \%$ trifluoroacetic acid in dichloromethane during $90 \mathrm{~min}$ followed by evaporation of the solvent. The product was transformed in amino form by dissolution in $10 \%$ triethylamine in dichloromethane for $1 \mathrm{~h}$ at room temperature followed by the evaporation of the solvent. The yield was $98 \%$.

Insertion of the isothiocyanate group. Amino-modified fluorophores $(5,6 \mu$ moles $)$ were dissolved in absolute ethanol (150 $\mu \mathrm{L})$, then carbon disulfide (56 $\mu$ moles) and triethylamine $(5,8$ $\mu$ moles) were added and the mixture was incubated $90 \mathrm{~min}$ at room temperature. Then the mixture was cooled to $0^{\circ} \mathrm{C}$ and di-tert-butyl dicarbonate $(5,5 \mu$ mole in $2 \mu \mathrm{L}$ of the absolute ethanol) and 4dimethylamionopyridine $(0,14 \mu$ moles in $1 \mu \mathrm{L}$ of the absolute ethanol) were added under stirring. The mixture was stirred overnight at room temperature. The solvents were evaporated and the products purified by preparative reversed-phase HPLC [19]. Yields were $44 \%$ for Rh-ITC and almost quantitative for OG-ITC.

\subsection{Murine cell culture experiments [15]}

The NIH-3T3 or MEF cell lines were grown in T75 culture flasks at $37{ }^{\circ} \mathrm{C}$ in $5 \% \mathrm{CO}_{2}$ atmosphere in Dulbecco's modified Eagle's medium (DMEM) supplemented with 10\% fetal bovine serum (FBS). Every 2 to 3 days, cells were trypsinized for $5 \mathrm{~min}$ at $37^{\circ} \mathrm{C}$ and resuspended in fresh medium.

For experiments with fixed cells, $10^{5}$ cells resuspended in the culture medium $(300 \mu \mathrm{L})$ were deposited on $22 \times 22 \mathrm{~mm}$ coverslips cleaned with a plasma cleaner Femto v4 (Diener electronic $\mathrm{GmbH}$ ) with an even thickness of $0.17 \pm 0.01 \mathrm{~mm}$ (Thermo Fisher Scientific Menzel) and deposited in 6-well plates. After 2 hours, a fresh medium $(2 \mathrm{~mL})$ was added to each well and cells were further grown until $70 \%$ confluence on the following day. The coverslips were washed three times in PBS, fixed with $4 \%$ paraformaldehyde (PFA) in PBS for 10 minutes at room temperature and washed three times with PBS. Fixed cells were stored at $4{ }^{\circ} \mathrm{C}$.

For experiments with live cells, $3 \times 10^{4}$ cells resuspended in the culture medium $(200 \mu \mathrm{L})$ were deposited on glass gridded ibiTreat $\mu$-slides (Ibidi, Biovalley). After 24 hours, the medium was removed and replaced with a solution containing fresh medium $(199 \mu \mathrm{L})$ and fluorescent polyamide solution $(1 \mu \mathrm{L}, 400 \mu \mathrm{M})$ in DMSO for a final polyamide concentration of $2 \mu \mathrm{M}$. Cells were incubated at $37{ }^{\circ} \mathrm{C}\left(5 \% \mathrm{CO}_{2}\right)$ for $24 \mathrm{~h}$. Before fluorescent microscopy, the cells were washed twice with PBS to remove excess compounds and the PBS was replaced under sterile conditions with modified media for imaging $\mathrm{DMEM}^{\text {gfp }}$ (Euromedex) supplemented with Rutin $(16 \mu \mathrm{M})$ and incubated 30 min at $37{ }^{\circ} \mathrm{C}$.

\subsection{Human cell culture experiments}

The Human cell line RPE-1 was cultivated in T75 culture flasks containing $10 \mathrm{~mL}$ of liquid medium RPMI (Roswell Park Memorial Institute medium) supplemented by $10 \%$ FBS under controlled atmosphere $\left(5 \% \mathrm{CO}_{2}, 37^{\circ} \mathrm{C}\right)$. Every 2 to 3 days the cells were treated with a trypsin solution $5 \mathrm{~min}$ at $37^{\circ} \mathrm{C}$, diluted and resuspended in a fresh medium.

All the experiments with the fixed and living human cells have been done according to the same protocols as for the murine ones, except the number of cells per sample. For the fixed cells, this number was $5 \times 10^{4}$ while for the living cells $-1.5 \times 10^{4}$.

\subsection{Labeling of fixed cells in situ.}

On the day of the experiment coverslips were fixed to $26 \times 76$ mm glass slides using rubber cement. Three types of experiments were performed.

For the combined visualization of fluorescent polyamides and DAPI, the fluorescent polyamide staining was first performed by 
incubating the slides in the dark for $30 \mathrm{~min}$ at room temperature in a solution containing PBS 1X $(199 \mu \mathrm{L})$ and the fluorescently labeled polyamide solution $(1 \mu \mathrm{L}, 400 \mu \mathrm{M})$ in DMSO for a final polyamide concentration of $2 \mu \mathrm{M}$. Then cells were washed briefly with PBS before the post-fixation step which consisted in incubating the cells with $2 \%$ PFA in PBS $(100 \mu \mathrm{L})$ for $10 \mathrm{~min}$, then rinsing three times in $\mathrm{PBS} / 0.05 \%$ TritonX-100. The nuclear DNA staining was performed by addition of a DAPI solution (70 $\mathrm{nM}$, Sigma-Aldrich) for $5 \mathrm{~min}$ at room temperature, then, after a brief washing step in PBS, the coverslips were mounted by removing the rubber cement and turning the coverslips upside down onto a clean $26 \times 76 \mathrm{~mm}$ slide. A drop of PPD8 mounting medium (Sigma-Aldrich, $1 \mathrm{mg} / \mathrm{mL}$ solution in PBS $/ 90 \%$ glycerol, pH 8 adjusted with carbonate/bicarbonate buffer, $\mathrm{pH}$ 9.6) was deposited. Finally, the slides were pasted by varnish and stored at $4^{\circ} \mathrm{C}$ for a short storage or at $-20^{\circ} \mathrm{C}$ for a long one.

For the combined visualization of fluorescent polyamides and FISH probes, the cells were permeabilized with Triton X-100 in PBS $(0.1 \%)$, rinsed three times with PBS, treated with $0.1 \mathrm{~N} \mathrm{HCl}$ for $2 \mathrm{~min}$, rinsed twice, equilibrated $5 \mathrm{~min}$ in $2 \mathrm{X} \mathrm{SSC}$ and treated with $2 \mathrm{X} \mathrm{SSC} / 50 \%$ deionized formamide at room temperature for at least 30 min prior to hybridization. The "mouse" FISH probe was a mixed DNA/LNA oligonucleotide targeting murine major satellite (5'-gACgACtTGaAAaATgACgAAaTC-3', where small letters indicate LNA modifications) labeled with $\mathrm{Cy} 3$ at its 3'-end. The "human" FISH probe was a full LNA oligonucleotide 5'tttgtgatgtgtg- 3' ("PCY") also labeled by $\mathrm{Cy} 3$ at 3'-terminus and targeted to positions 17-29 of the human $\alpha$-satellite repeat sequence consensus. The hybridization solutions were prepared upon diluting the oligonucleotide probe to a final concentration of $1 \mu \mathrm{M}$ in a hybridization solution (2X SSC, $\mathrm{pH}$ 5.6, $50 \%$ deionized formamide, Denhart solution, $10 \%$ dextran sulfate, $0.1 \%$ SDS). The hybridization solution $(45 \mu \mathrm{L})$ was added to the coverslip on the slide. The coverslip was covered with Krups paper and heated for $3 \mathrm{~min}$ at $85^{\circ} \mathrm{C}$, then slowly cooled to $37^{\circ} \mathrm{C}$ at a rate of $1^{\circ} \mathrm{C} / \mathrm{s}$. This was performed in an in situ PCR apparatus (MJ Research). Each slide was washed twice in $2 \mathrm{X} \mathrm{SSC}$ at $63{ }^{\circ} \mathrm{C}$ and once in $2 \mathrm{X} \mathrm{SSC}$ at room temperature. The fluorescent polyamide staining was then performed as described above. The slides were mounted without further DNA staining.

For the combined visualization of polyamide probes and proteins by immunocytochemistry, the cells were permeabilized by $0.1 \%$ Triton X100 solution in PBS during $5 \mathrm{~min}$ at room temperature and following washing twice by PBS. After saturation in $1.5 \%$ "blocking reagent" solution with $0.05 \%$ Tween 20 in $2 \mathrm{X} \mathrm{SSC}, \mathrm{pH} 6.3$, the cells were incubated with primary antibodies during $90 \mathrm{~min}$ at room temperature in a humid chamber, washed 3 times by $0.1 \%$ Triton X100 in PBS, then incubated with secondary antibodies $45 \mathrm{~min}$ at room temperature in a humid chamber in the dark and washed 3 times by $0.1 \%$ Triton X100 solution in PBS.

All the antibodies were diluted in $1 \%$ " blocking reagent" in PBS. The primary antibodies were the following: for detection of murine centromeres - rabbit polyclonal anti-CenpB (clone H65, 1/200, Santa Cruz), for detection of pericentromeres rabbit polyclonal anti-H3K9me3 (1/400, Upstate, Millipore). The secondary antibodies were the goat anti-rabbit antibodies labeled either with $\mathrm{Cy} 3$ or with Cy5 (Jackson ImmunoResearch).

In the immuno-FISH experiments, after immunochemical labeling the cells were post-fixed in $2 \%$ PFA in PBS during 10 min, washed 3 times by $0.1 \%$ Triton X100 in PBS and the FISH protocol was then applied. For simultaneous detection of both FISH and polyamide probes, the FISH protocol was applied first and followed by treatment with the fluorescent polyamide probes.

\subsection{Image acquisition [15]}

Images were recorded with a Zeiss epifluorescence inverted microscope (Axio Observer ZI) equipped with a Hamamatsu ORCA R2 camera, a plan apochromatic $63 \times 1.4$ NA oil-immersion objective and the following filters set: 49 shift free for Hoechst or DAPI (G365/FT395/BP44/50), 38 HE shift free for FITC (BP470/40, FT495, BP525/50), home-made sets for Cy3 (BP 546/10, FF555, BP 583/22) and for Cy5 (BP643/20, FF660, $\mathrm{BP} 684 / 24)$. Immersion oil of refractive index 1.518 at $23^{\circ} \mathrm{C}$ was used. The light source was LED illumination (wavelengths: 365 $\mathrm{nm}, 470 \mathrm{~nm}$ or $625 \mathrm{~nm}$ ) except for Cy3 where a metal halide lamp HXP120 was preferred. The Zen software was used for image acquisition.

\section{Results and discussion}

\subsection{Polyamides and target sequences}

Hairpin pyrrole-imidazole polyamides are peptide-like oligomers that are able to specifically recognize DNA sequences and to bind to the minor groove of a double-stranded DNA. The recognition rules are well known and quite simple [20]. Polyamides can easily penetrate into living cells and interact with the target native DNA sequences [21]. After labeling by fluorophores, they can be used for direct fluorescent imaging of the DNA repeats in fixed and living cells $[1,15,22]$. We previously designed and characterized synthetic polyamide probes targeting major satellite DNA, a sequence that is highly abundant in the pericentromeric regions of mouse chromosomes $[15,18]$. These fluorescent probes were able to stain specifically pericentromeric heterochromatin foci, called chromocenters, in fixed cells [15]. The visualization of chromocenters was obtained for the first time in live cells using the fluorescein isothiocyanate conjugated probe. For the present study, the F1 polyamide (Fig. 1A) was conjugated to various other fluorophores (analogs of Cy series, Rhodamine, Oregon Green 488). Some of these conjugations involved coupling to the polyamide with an isothiocyanate group instead of N-hydroxysuccinimide or azide groups as active moieties.

The most abundant tandemly repeated sequence in the human genome is called $\alpha$-satellite. It is present at both centromeres and pericentromeres. We have designed a 14 nucleotide probe (called PCY) for $\alpha$-satellite DNA based on the conservation of the target sequence within numerous $\alpha$-satellite DNA [23-25]. This probe labels large pericentromeric regions on almost all chromosomes, as revealed by FISH experiments (see further). The work performed in mouse cells suggested that target sequences as short as 6 bp may be sufficient for enabling tight and specific binding of the polyamide probes and successful visualization of pericentromeric repeats in live cells. Nevertheless, we were interested in investigating the possibility of using longer polyamides. We chose as a model a truncated version of the target sequence of the PCY probe:

$$
\text { 3' AAACACTACA 5' }
$$

We designed a series of polyamides with different hairpin lengths for the recognition of sequences ranging from 6 to 9 bp [26]. Previous work from the the group of Sugiyama has shown that replacing one or several $\mathrm{N}$-methylpyrroles by $\beta$ alanine units can make the polyamide molecules more flexible and adaptable to the DNA minor groove $[26,27]$. Therefore, such molecules were also included in our design. Fig. 1B summarizes all the molecules together with the DNA duplex target sequence used for the in vitro studies. 


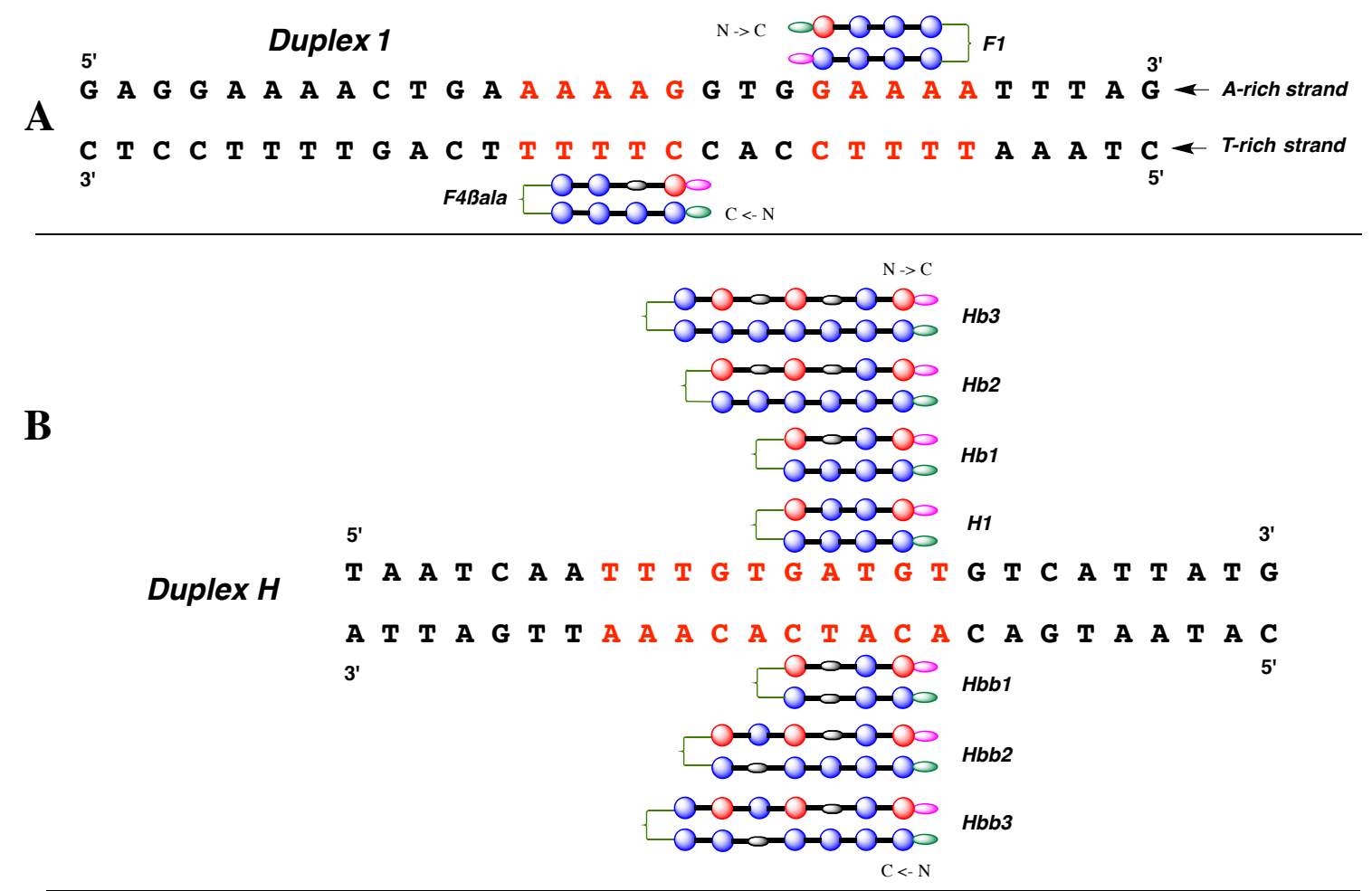

\section{Duplex C 5 '-GGGTGAGGAGGAGGAGATCGGTCAG-3'}

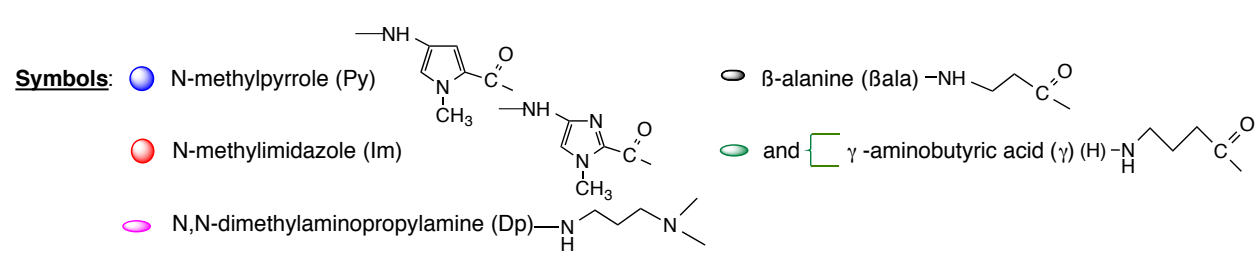

Figure 1. The model target DNA sequences and the pyrrole-imidazole polyamides used for the probe synthesis: A, for murine major satellite repeats, B, for human $\alpha$-satellite repeats. The target DNA sequences (in red) and the pyrrole-imidazole polyamides used for the probe synthesis are shown. Duplex 1 is a fragment from murine pericentromeric repeats, Duplex H is a model dsDNA fragment derived from human $\alpha$-satellite repeats for in vitro studies. Duplex $\mathrm{C}$ is a control duplex without any binding sites for all the murine and human polyamides.

The differences between the structures of human polyamides were in the length of the hairpin (from 4 to 7 monomer pairs), the number of the $\beta$-alanine moieties (from 0 to 2 ) and their positions (only in the $\mathrm{C}$-domain of each polyamide or both in its $\mathrm{N}$ - and $\mathrm{C}$ domains) (Fig. 1B). The identity of all the polyamides and probes was confirmed by mass-spectrometry (Tables S1 and S2, Supplementary materials).

\subsection{Studies of the interaction of human polyamides with their target DNA in vitro}

We studied first the interaction between synthesized polyamides and a synthetic DNA fragment containing the target DNA sequence in vitro (Duplex H, Fig. 1B). Several physicochemical methods were applied, such as DNA thermal denaturation, gel-shift experiments and circular dichroism of the complexes, as it was described in our previous publication [18]. The results were compared with those obtained in similar experiments performed using a control Duplex C (Fig. 1C) without any binding sites for the polyamides.

Table 1 shows the results obtained by thermal denaturation and gel-shift experiments. The apparent dissociation constants of the complexes were calculated from the gel-shift data [18]. The experimental results are in the Supplementary Materials (Fig. S1 and S2). All the polyamides form stable complexes with their target duplex (Duplex H); the apparent dissociation constants varied from 70 to $430 \mathrm{nM}$. The best affinity was demonstrated by the longer polyamides $\mathrm{Hb} 2$ and $\mathrm{Hb} 3$ (6-7 monomer pairs) containing two $\beta$-alanine residues in the $\mathrm{C}$-terminal domain of the hairpin. A weak non-specific interaction with the non-cognate duplex (Duplex C) was revealed by thermal denaturation (maximal increase of the duplex denaturation temperature $\Delta \mathrm{T}_{\mathrm{m}}$ upon complex formation was less than $5^{\circ} \mathrm{C}$ ), but it was not seen in gel shift experiments. 
Table 1. Increase of the dissociation temperatures of the duplexes $\mathrm{H}$ and $\mathrm{C}(\Delta \mathrm{Tm})$ upon their complex formation with the polyamides and apparent dissociation constants of the complexes "Duplex $\mathrm{H} /$ polyamide" determined by gel shift experiments.

\begin{tabular}{|c|c|c|c|}
\hline Polyamide & $\begin{array}{c}\Delta \mathrm{Tm} \text { in a complex } \\
\text { with the Duplex } \mathrm{H}^{\mathrm{a}},{ }^{\circ} \mathrm{C}\end{array}$ & $\begin{array}{c}\Delta \mathrm{Tm} \text { in a complex } \\
\text { with the Duplex } \mathrm{C},{ }^{\circ} \mathrm{C}\end{array}$ & $\begin{array}{c}\text { Dissociation constant of the } \\
\text { complex with the Duplex } H\left(K_{d}\right) \text {, } \\
\mu \mathrm{M}\end{array}$ \\
\hline Hb1 & $\geq 20^{*}$ & 4 & $0,17 \pm 0,02$ \\
\hline Hb2 & $\geq 20^{*}$ & 4,5 & $0,07 \pm 0,004$ \\
\hline Hbb2 & 16 & 3 & $0,085 \pm 0,005$ \\
\hline $\mathrm{Hb3}$ & 15 & 2 & $0,09 \pm 0,01$ \\
\hline Hbb1 & 14 & 3 & $0,38 \pm 0,01$ \\
\hline H1 & 12,3 & 2 & $0,43 \pm 0,015$ \\
\hline Hbb3 & 12 & 1 & $0,38 \pm 0,01$ \\
\hline
\end{tabular}

${ }^{\text {a }}$ Melting temperature of the duplex $\mathrm{H}$ alone was $64^{\circ} \mathrm{C} .{ }^{*}$ Melting temperature of the complex was close to the upper limit of the instrument's operational temperature $\left(85^{\circ} \mathrm{C}\right)$.

When a polyamide was in excess ( $>2$ times), a second retarded band with a lower mobility was observed (Fig. S1, Supplementary Materials). It can be due to the formation of a triple complex "DNA/2 polyamides" when two halves of each polyamide are located in the minor groove of the target duplex in an antiparallel orientation (Fig. S3, Supplementary Materials).

The comparison of different polyamide structures shows that the insertion of a $\beta$-alanine synthon instead of $\mathrm{N}$ methylpyrrole into the $\mathrm{C}$-terminal part of hairpins is favorable for the polyamide affinity $(\mathrm{Hb} 1, \mathrm{Hb} 2$ et $\mathrm{Hb} 3)$. In contrast, the insertion of the $\beta$-alanine residue into the $\mathrm{N}$-terminal part of the polyamides (Hbb1, Hbb2 et $\mathrm{Hbb3}$ ) seems to be unfavorable and decreases the polyamide affinity.

The circular dichroism experiments revealed slightly different forms of spectra for the different DNA-polyamide complexes (Fig. S4, Supplementary materials). However, when compared with the model spectra profiles published by the group of Gursky [28], these profiles are more similar to those ones when the polyamides maintain hairpin antiparallel conformation in the duplex minor groove $[18,29]$.

\subsection{Polyamide labeling by fluorophores, physico-chemical} and fluorescent properties of the synthesized probes.

Taking into account our previous results $[15,18]$, we decided to label all the polyamides by fluorescein isothiocyanate. The labeling method was the same as in the mentioned publications. The studies of the interaction between the probes and their target DNA by gel shift and thermal denaturation methods also revealed a strong decrease of the affinity after the fluorophore conjugation. In the gel shift experiments, the formation of a complex resulted in the retardation of the duplex migration with an increase of the polyamide concentration. However, no distinct bands of duplexes and complexes were observed and the smear between the bands did not permit to calculate apparent dissociation constants of the complexes (data not shown).

Table 2 shows the results of the experiments on the thermal stability of the DNA-probe complexes. A strong decrease of the melting temperature of these complexes was observed compared to those of non-labeled polyamides, which demonstrates a decrease of the affinity upon labeling as it was observed for the murine probes $[15,18]$.

The circular dichroism spectra of the DNA-probe complexes have a similar form as the complexes of non-labeled polyamides thus indicating the same binding mode and conformation (Fig.S5,
Supplementary Materials). However, the spectrum amplitudes, especially for short polyamides, are not so high as those of the free polyamides. It is in agreement with our previous results obtained with "murine" probes $[15,18]$.

Table 2. Increase of the dissociation temperatures of the duplexes $\mathrm{H}$ and $\mathrm{C}(\Delta \mathrm{Tm})$ upon their complex formation with the polyamide probes labeled by fluorescein.

\begin{tabular}{lcc}
\hline Probe & $\begin{array}{c}\Delta \text { Tm in a complex } \\
\text { with the Duplex } \mathrm{H}^{*}, \\
{ }^{\circ} \mathrm{C}\end{array}$ & $\begin{array}{c}\Delta \text { Tm in a complex } \\
\text { with the Duplex } \mathrm{C}, \\
{ }^{\circ} \mathrm{C}\end{array}$ \\
\hline Hb2-FITC & 9 & $\leq 1$ \\
Hb1-FITC & 5,5 & $\leq 1$ \\
Hbb1-FITC & 4,5 & $\leq 1$ \\
Hb3-FITC & 4 & $\leq 1$ \\
Hbb2-FITC & 3,5 & $\leq 1$ \\
H1-FITC & 2,2 & $\leq 1$ \\
Hbb3-FITC & 2 & $\leq 1$
\end{tabular}

*Melting temperature of the duplex $\mathrm{H}$ alone was $64^{\circ} \mathrm{C}$

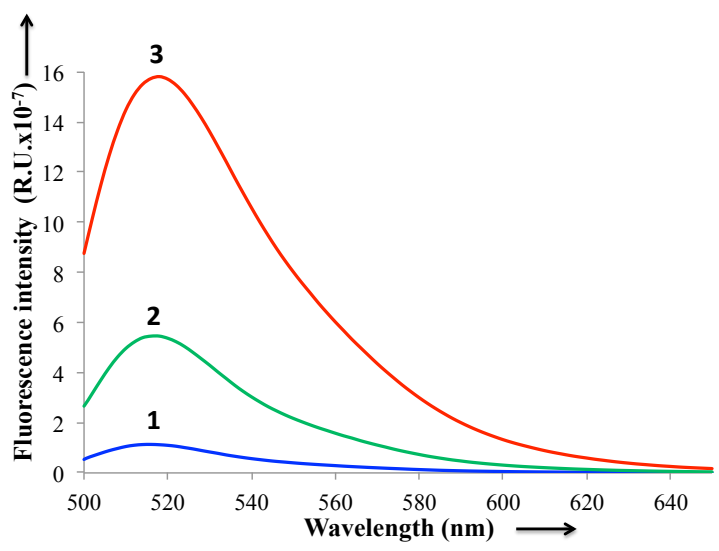

Figure 2. Fluorescence spectra of the human probe Hb1-FITC in the absence of DNA (1), in the presence of the non-cognate duplex $\mathrm{C}$ (2) and of the target duplex $\mathrm{H}$ (3) in Tris- $\mathrm{HCl}$ buffer (10 mM, pH 7.5), $50 \mathrm{mM} \mathrm{NaCl}, 50 \mathrm{mM} \mathrm{KCl}$ and $1 \mathrm{mM} \mathrm{MgCl}$. DNA and probe concentrations are $2 \mu \mathrm{M}$. Excitation at 480 $\mathrm{nm}$.

Similar to the mouse fluorescein-labeled probes, the human fluorescent polyamides demonstrate a high increase of the 
fluorescence emission upon the formation of the complex with the target DNA. The highest emission increase (17 times) has been obtained for the complex of duplex $\mathrm{H}$ with the labeled polyamide Hb1 (Fig. 2). A weak non-specific interaction with the noncognate duplex leads to the increase of the fluorescence, but with much less intensity (Table 3, Fig. 2).

Table 3. Increase of the fluorescence emission intensity (fold) of the polyamide probes upon their interaction with the target $(\mathrm{H})$ and non-cognate (C) DNA duplexes. Conditions - see legend to figure 2

\begin{tabular}{lcc}
\hline Probe & Duplex H & Duplex C \\
\hline Hb1-FITC & $\times 17$ & $\times 4,5$ \\
Hb2-FITC & $\times 9,5$ & $\times 3,5$ \\
Hb3-FITC & $\times 3$ & $\times 1,1$ \\
Hbb2-FITC & $\times 2,9$ & $\times 1,2$ \\
H1-FITC & $\times 1,9$ & $\times 1,1$ \\
Hbb3-FITC & $\times 1,5$ & $\times 1,1$ \\
Hbb1-FITC & $\times 1,4$ & $\times 1,1$ \\
\hline
\end{tabular}

The fluorescence emission increase upon interaction of fluorescent polyamides with the target DNA correlates with (but does not follow) the affinity of the targeting polyamides determined by thermal denaturation and gel shift methods (Tables 2 and 3 ).

\subsection{The interaction of murine polyamide probes with murine fixed and living cells}

In our previous communication [15], we selected two most affine polyamides targeted to murine DNA sequences. We labeled them by different fluorophores and demonstrated that the probes are able to stain chromocenters in fixed murine cells MEF and NIH-3T3. In living cells, only the probes labeled with the fluorescein isothiocyanate (FITC) were able to visualize specifically the pericentromeric heterochromatin foci. In the present work, we approved the probes' specificity, studied the roles of the fluorophore nature and tried to apply several treatments known to improve cell penetration of the synthetic probes.

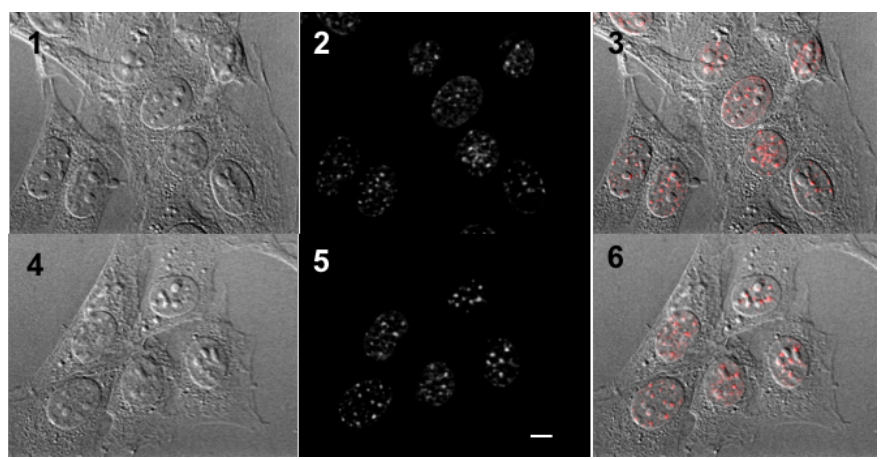

Figure 3. Images of fixed murine cells NIH-3T3 stained with $2 \mu \mathrm{M}$ F1-Cy3 (1-3) and F4ß-Cy5 (4-6) during $30 \mathrm{~min} .1$ and 4, bright field; 2, F1Cy3 staining; 5, F4ß-Cy5 staining; 3, overlay of 1 and 2; 6, overlay of 4 and 5 . Scale bar: $10 \mu \mathrm{m}$.
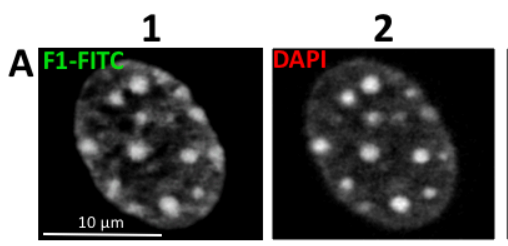

3
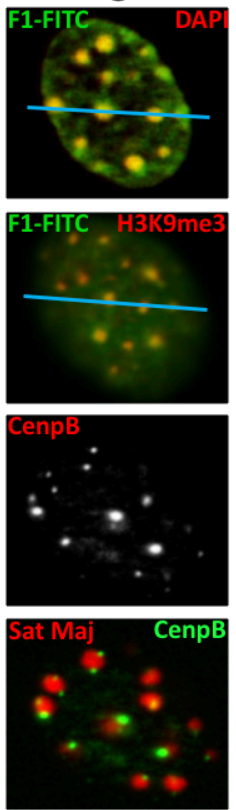

4

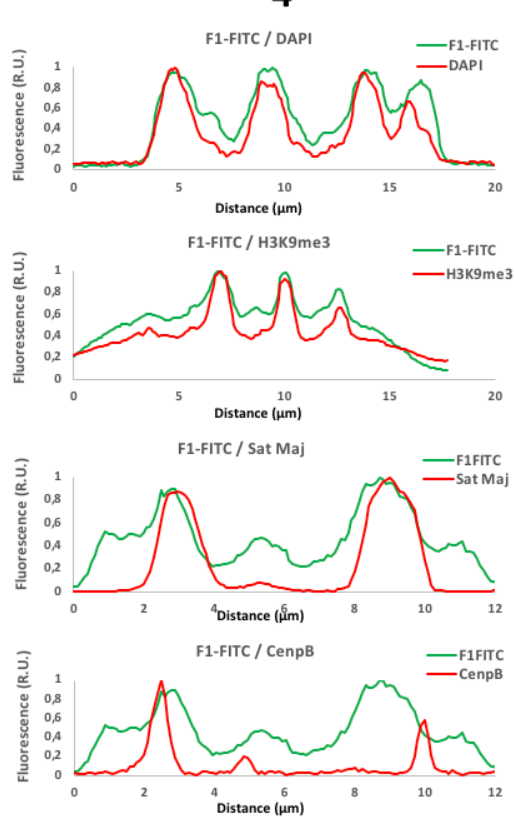

Figure 4. Images of nuclei in fixed murine cells NIH-3T3 stained with $2 \mu \mathrm{M}$ F1-FITC (A1, B1, C1) during 30 min and then treated with pericentromere-specific markers DAPI (A2), H3K9me3 (B2) and oligonucleotide probe SatMaj (C2), as well as with centromere-specific marker CenpB (C3). The images were overlaid as it is indicated on the pictures: A3, F1-FITC (green) + DAPI (red); B3, F1-FITC(green) + H3K9me3 (red); D1, F1-FITC (green) + SatMaj (red); D2, F1-FITC (green) + CenpB (red); D3, SatMaj (red) + CenpB (green). An arbitrary axe was drawn on each overlay image and the fluorescence intensity of both signals was measured along this axe. The intensity profiles along the axes shown in A3, B3, D1 and D2 are shown in column 4 . Scale bar: $10 \mu \mathrm{m}$. 
Fig. 3 shows images of fixed NIH-3T3 murine cells stained with $2 \mu \mathrm{M}$ polyamide probes F1-Cy3 and F4ß-Cy5 during $30 \mathrm{~min}$. A punctuated labeling pattern typical of chromocenters is observed. Similar images were obtained with the polyamides labeled by fluorescein, fluorescein isothiocyanate, different cyanine and coumarin dyes [18] (data not shown). We note here that this pattern is obtained provided a post-fixation is performed. This suggests that the interaction of the probes with their target is very labile and does not resist the washing steps that are required for removing unbound probes in those experiments.

In order to prove the specificity of the staining, we compared the localization of the polyamide probes and that of the known markers of centromeric and pericentromeric regions. We used DAPI (who is a marker for chromocenters in murine cells), a Cy3-labeled chimeric LNA/DNA oligonucleotide (SatMaj, 5'gACgACtTGaAAaATgACgAAaTC-3'-Cy3, lower-case letters indicate LNA units) targeted to one of the pericentromere repeated sequences, and an anti-H3K9me3 antibodies detected then by immunofluorescence method. For negative control, the histone CenpB, which is a centromere marker, was also stained using immunofluorescence detection with anti-CenpB antibodies (Fig. 4). As it is seen on the Fig. 4, the polyamide probe F1-FITC perfectly co-localizes with all the pericentromere markers. Quantitative analysis of the scan data demonstrates that $87 \%$ of the F1-FITC signal colocalize with the DAPI signal (19 nuclei, Pearson coefficient 0,82), 97\% - with the H3K9me3 signal (16 nuclei, Pearson coefficient 0,88) and $98 \%$ - with the Sat Maj (10 nuclei, Pearson coefficient 0,65). In contrast, the signal of centromere-specific histone CenpB does not co-localize with that of pericentromere-specific probes (Fig. 4, D4). There is a low probe signal and no signal co-localization with the pericentromere markers when the DNA-binding polyamide F1 is replaced by another one F2 that possesses a low affinity for the targeted DNA sequence (see $[15,18]$, fig S6).

In the living cells, according to our previous data, FITC appeared to be a suitable fluorophore to label the polyamides for the visualization of pericentromere regions [15]. All the other fluorophores (cyanines, coumarins, rhodamines) strongly affect the nuclear penetration of the polyamide probes. Fig. 5 demonstrates a typical example of the cellular distribution of the cyanine-labeled probes in NIH-3T3 murine cells. The polyamides labeled by $\mathrm{Cy} 3$ or $\mathrm{Cy} 5$

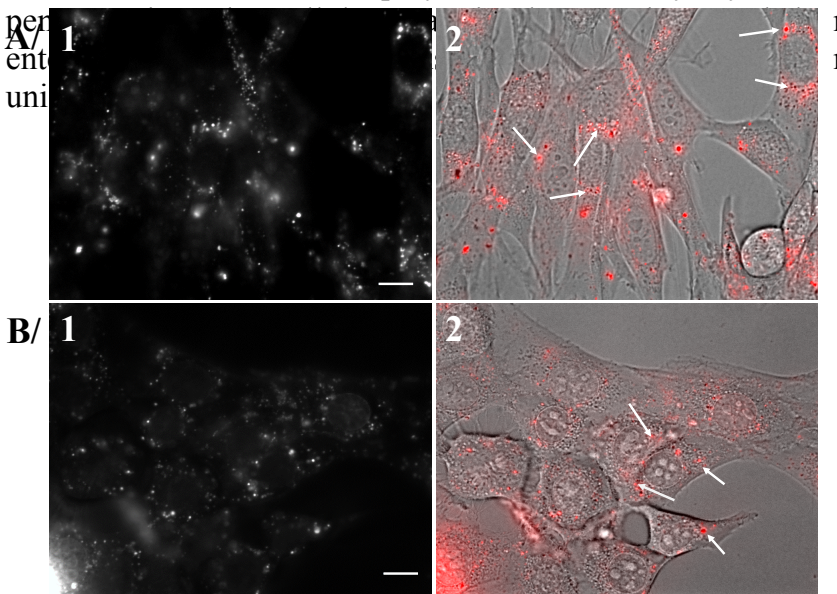

Figure 5. Images of living cells NIH-3T3 treated with $2 \mu \mathrm{M}$ F1-Cy3 (A) and F4ß-Cy5 (B) during $24 \mathrm{~h}$. 1, fluorescence; 2 , overlay of the images with the fluorescence of F1-Cy3 (A2) and F4ß-Cy5 (B2) in red and cells in bright field in gray. Some aggregates are indicated by the arrows. Scale bar: $10 \mu \mathrm{m}$.
FITC probes allowed a specific visualization of the targeted pericentromeric sequences in murine live cells, in contrast to probes where fluorescein was conjugated with N-hydroxysuccinimide or azide groups (Figure S7, Supplementary). Therefore, we undertook the synthesis of several other fluorophores bearing this isothiocyanate group for the polyamide coupling. Thus, we synthesized several cyanine fluorophores, analogs of $\mathrm{Cy}$ series and other known fluorophores (Rhodamine, Oregon Green 488) with an isothiocyanate group instead of N-hydroxysuccinimide or azide groups as active moieties. Among them, only the probes labeled by the Oregon Green 488 isothiocyanate (OG-ITC) (Fig. 6 and S8, Supplementary Materials) demonstrated a similar punctuated staining of the murine

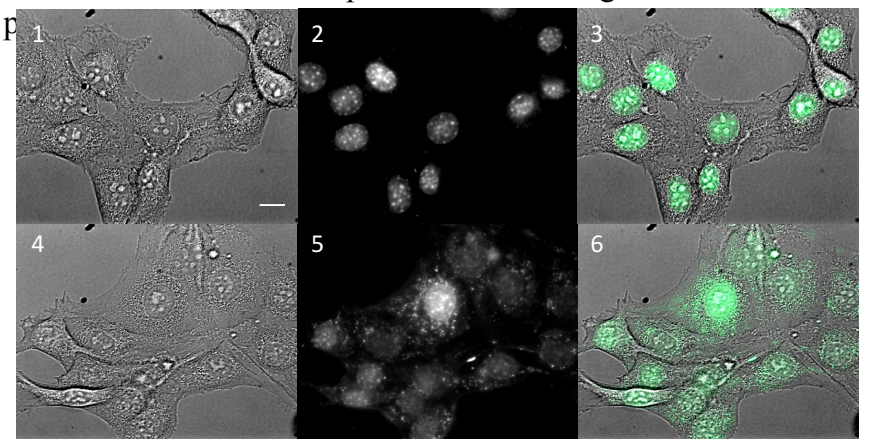

Figure 6. Images of living cells NIH-3T3 treated with $2 \mu \mathrm{M}$ F1-FITC (1-3) or F1-OG-ITC (4-6) during $24 \mathrm{~h}$ in 3T3 medium without fetal bovine serum in the presence of $16 \mu \mathrm{M}$ rutin (to decrease bleaching) and DMEMgfp. 1, 4, bright field; 2,5 , fluorescence; 3,6 , overlay of both images. Scale bar: $10 \mu \mathrm{m}$.

Several factors may limit the penetration of probes into the cell nuclei in a fluorophore dependant manner. The first of them if the formation of aggregates. Hargrove et al. [30] used an addition of 2-hydroxypropyl- $\beta$-cyclodextrin to the medium in order to solubilize pyrrole-imidazole polyamide aggregates. We tried to use this method to improve the nuclear penetration of our probes. Fig. 7 shows that with the addition of $3 \mathrm{mM} \mathrm{2-}$ hydroxypropyl- $\beta$-cyclodextrin, the aggregation was strongly reduced but not completely suppressed and the nuclear penetration of the probes was not improved. This also holds true for the use of a medium deprived of fetal bovine serum.
1
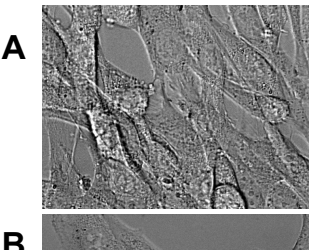

2

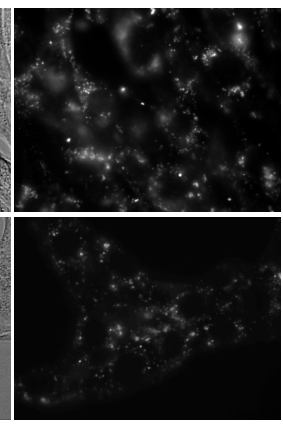

3

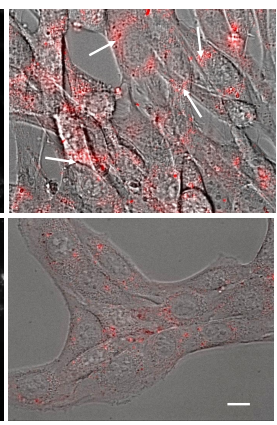

Figure 7. Images of living cells NIH-3T3 treated with $2 \mu \mathrm{M}$ F1-Cy3 during 24 $\mathrm{h}$ in the presence of $3 \mathrm{mM} 2$-hydroxypropyl- $\beta$-cyclodextrin (A) and in the 3T3 medium deprived of fetal bovine serum (B). 1, bright field; 2, fluorescence; 3 , overlay of both images. Some aggregated are indicated by the arrows. Scale bar: $10 \mu \mathrm{m}$.

Another one is the permeability of the nuclear membrane. We decided to incubate the cells with the Cy5-labeled probes in the presence of detergents $(0,05 \%$ Tween 20 or $0,01 \%$ Saponine). This resulted in the penetration of the fluorescent material into the nucleus, but its distribution was not punctuated and the cells changed their morphology. They became rounded and granule-like (Fig. S9, supplementary materials). Although cells are likely no 
more viable at this step, such an experiment shows that nuclear entry is not sufficient for enabling the labeling of heterochromatin using Cy5-modified probes. The same was true for Cy3-labeled probes. One explanation for this observation may be the lower affinity of these probes for their target, which may not be sufficient for enabling observation of the targeted DNA in living cells. We also tried to generate micro-pores in the cell membranes using electroporation method with Amaxa(C system, but we did not obtain better nuclear penetration, in contrast, high level of cell death has been observed when electroporation method has been applied (data not shown).

Finally, we must mention that photobleaching represents a serious limit when one want to undertake labeling of nuclear structures in live cells. This bleaching can be attributed to the generation of free radicals under the UV irradiation. Our initial attempts led us to chose for observation of living cells a special medium $\mathrm{DMEM}^{\mathrm{gfp}}$, depleted of two radical-generating vitamins (riboflavin and pyridoxal) in the presence of $16 \mu \mathrm{M}$ rutin, a natural flavonoid from plants that captures and eliminates free radicals from the medium (Fig. 6) [31]. This resulted in an apparent increased life time of the signal, probably by decreasing the radical production and quenching produced radicals. Nevertheless, it was not possible to extend the observation over a few seconds under the fluorescence microscope, due to a quick bleaching of the fluorescent signal (Figure S10, Supplementary materials).

In conclusion, the imaging of the DNA in living murine cells with fluorescent polyamide probes appeared to be very sensitive not only to the structure of the polyamides and targeted DNA sequence, but also to the nature of conjugated fluorophores. All the fluorophores after conjugation strongly decreased the polyamide-DNA affinity and the majority of them had limited the nuclear penetration and aggregated in the cytoplasm. Thus, the main question remains the fluorophore nature. More stable fluorophores that do not prevent the nuclear penetration and do not stimulate the probe aggregation are needed.
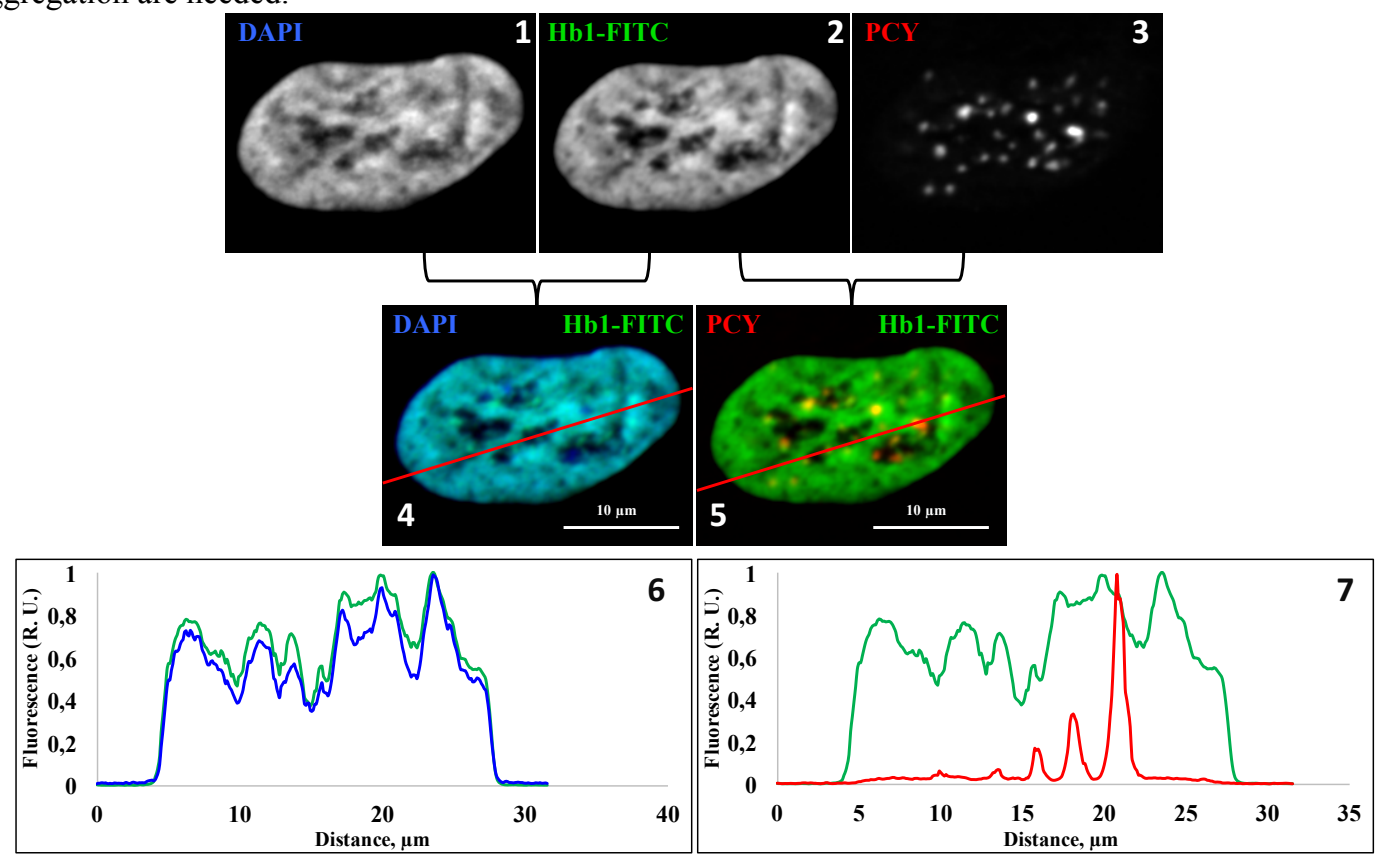

Figure 8. Images of nuclei of fixed human cells RPE-1 incubated with $70 \mathrm{nM}$ DAPI (1), $2 \mu \mathrm{M}$ Hb1-FITC (2), and $1 \mu \mathrm{M}$ LNA oligonucleotide PCY (3). For LNA hybridization, the cellular DNA was denatured by heating at $85^{\circ} \mathrm{C}$. The images were overlaid as it is indicated on the pictures: 4, Hb1-FITC/DAPI, 5, Hb1FITC/PCY. An arbitrary axe was drawn on each overlay image and the fluorescence intensities of both signals were measured along this axe. The intensity profiles are shown on pictures 6 and 7, green Hb1-FITC, blue DAPI and red PCY. Scale bar: $10 \mu \mathrm{m}$.

\subsection{Interaction of human polyamide probes with human}

fixed and living cells

Recent data from our group suggest that human $\alpha$ satellite centromeric repeats are able to associate and to form nuclear structures similar to murine chromocenters [32, 33]. In particular, a FISH probe targeting numerous $\alpha$-satellite repeats labels foci in the nucleus of human cells (Fig. 8). We decided to study the interaction of human probes with fixed and living RPE-1 human cells. Fig. 9 shows a typical example of human cell imaging after incubation of fixed RPE-1 cells with $2 \mu \mathrm{M} \mathrm{Hb} 1$-FITC probe during $30 \mathrm{~min}$. As it is seen on the picture, all the DNA in the nuclei is stained by the probe. Thus, a total non-specific staining is observed. Very similar images were obtained for all the human probes in both RPE-1 and GM12878 cell lines (data not shown). provided by the FISH probe for $\alpha$-satellite repeats and by the newly synthesized polyamide probes targeting the same sequences. As it is seen on the Fig. 8, the Hb1-FITC polyamide probe stains fixed nuclei from RPE-1 cells in a similar way as does DAPI, but does not stain the foci that are revealed with the FISH probe. A similar staining was obtained using all the $\alpha$-satellite targeted polyamide probes, suggesting that the polyamide probes do not achieve specific staining of

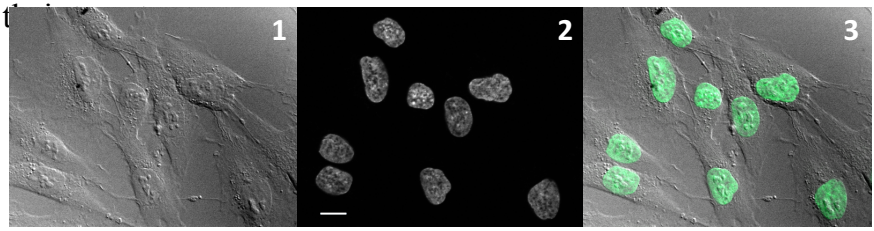

Figure 9. Images of fixed RPE-1 cells treated with $2 \mu \mathrm{M} \mathrm{Hb} 1$-FITC during $30 \mathrm{~min}$ in PBS solution. 1, bright field; 2, fluorescence; 3, overlay of both images. Scale bar: $10 \mu \mathrm{m}$.
Like for murine cells, we compared the labeling patterns 
Although the probes did not appear to be suitable for imaging heterochromatin foci in living human cells, none of the probes showed cytotoxicity. There was no difference in the morphology and the proliferation of the cells treated or nontreated by the polyamide probes. Concerning the cellular penetration, three types of images were obtained (Fig. 10).

1

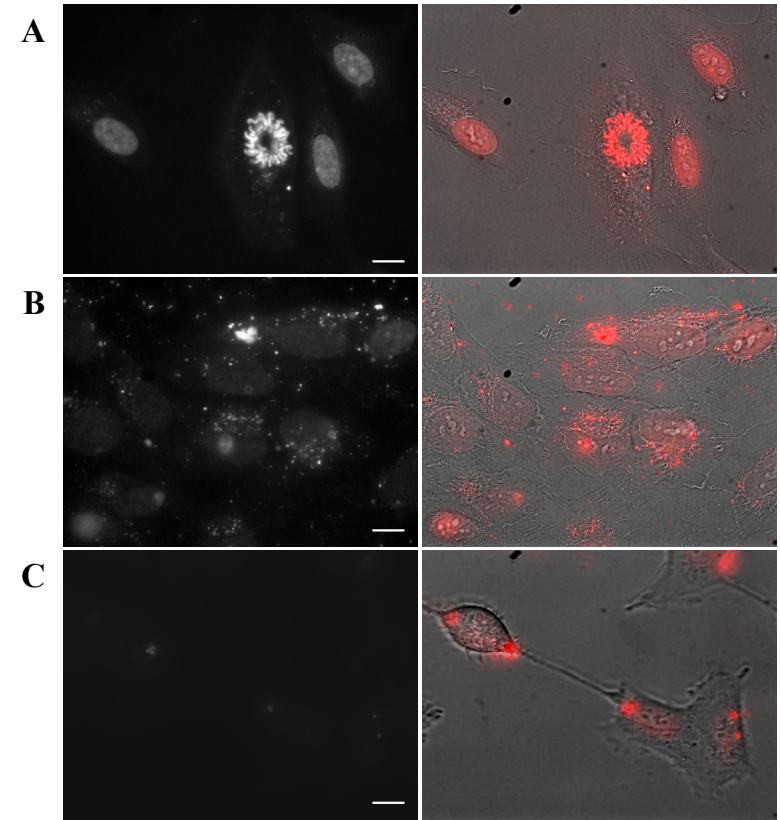

Figure 10. Images of living RPE-1 cells treated with $2 \mu \mathrm{M}$ polyamide probes during $24 \mathrm{~h}$ in RPMI $+10 \%$ FBS medium. 1, fluorescence; 2, overlay of bright field and fluorescence images. A, Hb1-FITC; B, H1-FITC; C, Hb2-FITC. Scale bar: $10 \mu \mathrm{m}$.

First, the probes Hb1-FITC and Hbb1-FITC reveal identical staining profiles: a uniform labeling of nucleus without any visible structures. A dividing cell with uniformly stained separating chromosomes is seen on the Fig 10A (one more proof of the absence of toxicity and a DNA-specific, but not a sequencespecific staining). Second, H1-FITC (without $ß$-alanine residue) shows a much lower nuclear penetration and a small aggregate formation (Fig 10B). So, the role of the $\beta$-alanine residue is not limited to bringing flexibility into the polyamide structure but it is also useful for improving the cell penetration. Finally, all the probes longer than 4 pairs of monomers (Hb2-FITC, Hbb2-FITC, Hb3-FITC et Hbb3-FITC) aggregate and do not penetrate into the nuclei (Fig 10C and S11, Supnlementarv Materials)

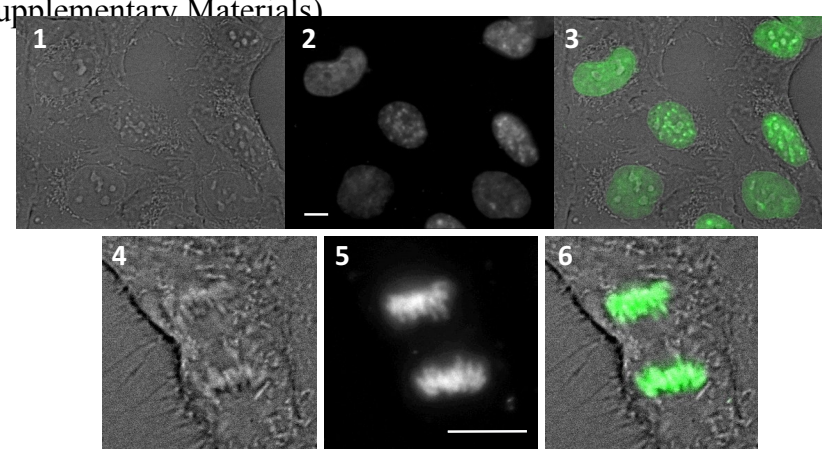

Figure 11. Images of living human RPE-1 cells treated with $2 \mu \mathrm{M}$ murine polyamide probe F1-FITC during $24 \mathrm{~h}$ in RPMI medium with $10 \%$ FBS. 1,4. bright field; 2,5, fluorescence; 3,6; overlay of bright field and fluorescence images. 1-3, several cells in the field, 4-6, zoom from another field demonstrating a dividing cell. Scale bar: $10 \mu \mathrm{m}$.
We performed several additional experiments in order to better understand the difference between both our experimental systems. When human RPE-1 living cells were treated with murine polyamide probe F1-FITC, a uniform staining of DNA in the cell nuclei was observed (Fig. 11). Zoomed photos 4, 5 and 6 show one cell in division with the visible chromosome segregation. It means that the short polyamide probes can be used as efficient non-toxic markers of the intracellular DNA in living cells for observations in dynamics. A similar uniform staining of DNA was observed when living murine NIH-3T3 cells were treated with the human polyamide probe $\mathrm{Hb} 1$ (Fig. S12, Supplementary Materials), while the F2-FITC probe, which did not reveal chromocenters in fixed murine cells, formed aggregates in the cytoplasm on living murine cells.

Taken together, these results demonstrate that sequencetargeted polyamide fluorescent probes are promising tools for DNA imaging in mammalian cells but that specific staining of pericentromeric heterochromatin using such probes is highly dependent on the nature of the polyamide sequence and of the attached fluorophore. The newly synthesized polyamides targeting $\alpha$-satellite sequences displayed high affinity for their target which could be enhanced by replacement of a single pyrrole residue by a $\beta$-alanine residue, while increasing the length of the polyamide could have a detrimental effect.

Conjugation of fluorophores resulted in a strong reduction of the affinity for the target, but some of the probes still bind efficiently to target DNA in vitro and show fluorescence enhancement upon binding. Nevertheless, while most probes targeting major satellite repeated sequences specifically stain pericentromeric heterochromatin in fixed murine cells, $\alpha$ satellite-targeted probes only revealed uniform staining all genomic DNA. This observation may be the result of: i) a different accessibility of DNA at the targeted chromatin in fixed human cells, ii) the higher polymorphism of human DNA repeats $[34,35]$ or iii) the lower relative density of binding sites for the polyamide probes in pericentromeric DNA compared to the rest of the genome in human cells (for human cells: one every 33 bp on pericentromeric DNA, one every $50 \mathrm{bp}$ for the rest of the genome; for murine cells: one evry $10 \mathrm{bp}$ for pericentromeric DNA, one in $31 \mathrm{bp}$ for the rest of the genome).

Experiments conducted in living cells demonstrated the absence of major cytotoxicity of polyamide probes: cells with labeled DNA are viable and can still proliferate. Nevertheless, the suitability of such probes for DNA imaging in cellulo is influenced by their composition or, more precisely, by the nature of the polyamide and the fluorophore. Nuclear penetration is favored by the use of isothiocyanate derivatives of fluorescein or Oregon Green and by the use of short polyamides containing a $\beta$-alanine residue instead of a pyrrole residue in the $\mathrm{C}$-terminal part of the polyamide hairpin. Photobleaching of these fluorophores remains a problem if one wants to make longer observations of living cells.

Future work could aim at improving the relative specificity of human probes for pericnetromeric DNA with respect to the rest of the genome. New tandem constructions via conjugation of two to four hairpin polyamides by a flexible linker may be envisioned, following the recent publications of Sugiyama's group [36, 37]. This approach works well in fixed cells for imaging of telomere repeats, but for living cells, according to our preliminary data (data not shown), formation of aggregates is observed. It should be interesting to modify the structure of the tandems by making them more hydrophilic, for example, by linking the hairpins with oligo(ethylene glycol) linkers. The other problem is the fluorophore nature. It is worth trying more photostable molecules than fluorescein, for example, described by Wagenknecht et al [38, 
39]. In order to reduce the masking of the target-bound probe signal by the background fluorescence, new fluorophores drastically changing the wavelengths of the fluorescent emission upon interaction with DNA could be used [40, 41].

\section{Conflict of interest}

The authors declare no conflict of interest.

\section{Acknowledgments}

This work was supported by MNHN, INSERM and CNRS. K.N. had a PhD scholarship from the National Museum of Natural History, Paris. We thank Drs. Alain Blond, Arul Marie and Mr. Lionel Dubost for NMR and mass spectra. Special thanks to Dr. Loïc Ponger for his help in the selection of the human $\alpha$-satellite sequences.

\section{Supplementary Material}

Supplementary materials are available at the WEB-site

\section{References and notes}

[1] A. Boutorine, D. Novopashina, O. Krasheninina, K. Nozeret, A. Venyaminova, Fluorescent Probes for Nucleic Acid Visualization in Fixed and Live Cells, Molecules, 18 (12) (2013) 15357-15397, doi: $10.3390 /$ molecules 181215357

[2] J. Nath, K.L. Johnson, A Review of Fluorescence in Situ Hybridization (FISH): Current Status and Future Prospects, Biotech. Histochem., 75 (2) (2000) 54-78, doi: 10.3109/10520290009064150

[3] J.M. Levsky, R.H. Singer, Fluorescence in situ hybridization: past, present and future, J. Cell Sci., 116 (14) (2003) 2833-2838, doi: $10.1242 /$ jcs. 00633

[4] B.A. Didion, S. Karmakar, D.C. Guenther, S.P. Sau, J.P. Verstegen, P.J. Hrdlicka, Invaders: Recognition of DoubleStranded DNA by Using Duplexes Modified with Interstrand Zippers of 2-O-(Pyren-1-yl)methyl-ribonucleotides, ChemBioChem, 14 (13) (2013) 1534-1538, doi: 10.1002/cbic. 201300414

[5] N. Sadoni, S. Langer, C. Fauth, G. Bernardi, T. Cremer, B.M. Turner, D. Zink, Nuclear Organization of Mammalian Genomes: Polar Chromosome Territories Build up Functionally Distinct Higher Order Compartments, J. Cell Biol., 146 (6) (1999) 12111226, doi 10.1083/jcb.146.6.1211.

[6] E.M.M. Manders, H. Kimura, P.R. Cook, Direct Imaging of DNA in Living Cells Reveals the Dynamics of Chromosome Formation, J. Cell Biol., 144 (5) (1999) 813-822, doi: 10.1083/jcb.144.5.813

[7] X. Wang, R. Reyes-Lamothe, D.J. Sherratt, Visualizing genetic loci and molecular machines in living bacteria (Biochemical Society Linked Focused Meetings), Biochem. Soc. Trans., 36 (4) (2008) 749-753, doi: 10.1042/BST0360749.

[8] W.H. De Vos, G.H. Joss, W. Haffmans, R.A. Hoebe, E.M.M. Manders, P. Van Oostveldt, Four-dimensional telomere analysis in recordings of living human cells acquired with Controlled Light Exposure Microscopy, J. Microsc., 238 (3) (2010) 254-264, doi: 10.1111/j.1365-2818.2009.03350.x.

[9] K. Sugimoto, K. Senda-Murata, S. Oka, Construction of three quadruple-fluorescent MDA435 cell lines that enable monitoring of the whole chromosome segregation process in the living state, Mutat. Res., Genet. Toxicol. Environ. Mutagen., 657 (1) (2008) 56-62, doi: 10.1016/j.mrgentox.2008.08.005.

[10] Y. Miyanari, C. Ziegler-Birling, M.-E. Torres-Padilla, Live visualization of chromatin dynamics with fluorescent TALEs, Nature Struct. Mol. Biol., 20 (11) (2013) 1321-1324, doi: 10.1038/nsmb.2680.

[11] H. Ma, P. Reyes-Gutierrez, T. Pederson, Visualization of repetitive DNA sequences in human chromosomes with transcription activator-like effectors, Proc. Nat. Acad. Sci. USA, $110 \quad$ (52) (2013) 21048-21053, doi: 10.1073/pnas. 1319097110.

[12] B. Chen, L.A. Gilbert, B.A. Cimini, J. Schnitzbauer, W. Zhang, G.-W. Li, J. Park, E.H. Blackburn, J.S. Weissman, L.S. Qi, B. Huang, Dynamic Imaging of Genomic Loci in Living Human Cells by an Optimized CRISPR/Cas System, Cell, 155 (7) (2013) 1479-1491, doi: 10.1016/j.cell.2013.12.001.

[13] T. Anton, S. Bultmann, H. Leonhardt, Y. Markaki, Visualization of specific DNA sequences in living mouse embryonic stem cells with a programmable fluorescent CRISPR/Cas system, Nucleus, 5 (2) (2014) 163-172, doi: 10.4161/nucl.28488.

[14] H.H. Ma, A. Naseri, P. Reyes-Gutierrez, S.A. Wolfe, S.J. Zhang, T. Pederson, Multicolor CRISPR labeling of chromosomal loci in human cells, Proc. Nat. Acad. Sci. USA, 112 (10) (2015) 30023007, doi: 10.1073/pnas. 1420024112 .

[15] K. Nozeret, F. Loll, C. Escudé, A.S. Boutorine, Polyamide Fluorescent Probes for Visualization of Repeated DNA Sequences in Living Cells, ChemBioChem, 16 (4) (2015) 549-554, $10.1002 /$ cbic. 201402676 .

[16] P.O. Krutzik, A.R. Chamberlin, Synthesis of DNA-binding polyamides. Robust solid-phase methods for coupling heterocyclic aromatic amino acids, in: L.B. English (Ed.) Meth. Mol. Biol., vol. 201, 2002, pp. 77-92.

[17] P.O. Krutzik, A.R. Chamberlin, Rapid solid-phase synthesis of DNA-binding pyrrole-imidazole polyamides, Bioorg. Med. Chem. Lett., 12 (16) (2002) 2129-2132, doi: 10.1016/S0960894X(02)00359-1.

[18] K. Nozeret, M. Bonan, S.M. Yarmoluk, D.S. Novopashina, A.S. Boutorine, Synthesis of mouse centromere-targeted polyamides and physico-chemical studies of their interaction with the target double-stranded DNA, Bioorg. Med. Chem., 23 (17) (2015) 59325945, doi: http://dx.doi.org/10.1016/j.bmc.2015.06.062.

[19] H. Munch, J.S. Hansen, M. Pittelkow, J.B. Christensen, U. Boas, A new efficient synthesis of isothiocyanates from amines using ditert-butyl dicarbonate, Tetrahedron Lett., 49 (19) (2008), 3117 3119, 10.1016/j.tetlet.2008.03.045.

[20] P.B. Dervan, B.S. Edelson, Recognition of the DNA minor groove by pyrrole-imidazole polyamides, Curr. Opin. Struct. Biol., 13 (3) (2003) 284-299, doi: 10.1016/S0959440X(03)00081-2.

[21] M.S. Blackledge, C. Melander, Programmable DNA-binding small molecules, Bioorg. Med. Chem. 21 (20) (2013) 6101-6114, doi: 10.1016/j.bmc.2013.04.023.

[22] A. Hirata, K. Nokihara, Y. Kawamoto, T. Bando, A. Sasaki, S. Ide, K. Maeshima, T. Kasama, H. Sugiyama, Structural Evaluation of Tandem Hairpin Pyrrole-Imidazole Polyamides Recognizing Human Telomeres, J. Am. Chem. Soc., 136 (32) (2014) 11546-11554, doi: 10.1021/ja506058e.

[23] J.C. Wu, L. Manuelidis, Sequence definition and organization of a human repeated DNA, J. Mol. Biol., 142 (3) (1980) 363-386, doi: 10.1016/0022-2836(80)90277-6.

[24] J.S. Waye, H.F. Willard, Structure, organization, and sequence of alpha satellite DNA from human chromosome 17: evidence for evolution by unequal crossing-over and an ancestral pentamer repeat shared with the human X chromosome, Mol. Cell. Biol., 6 (9) (1986) 3156-3165, doi: 10.1128/mcb.6.9.3156.

[25] B. Vissel, K.H. Choo, Human alpha satellite DNA - consensus sequence and conserved regions, Nucl. Acids Res., 15 (16) (1987) 6751-6752, doi: 10.1093/nar/15.16.6751.

[26] J. Syed, Ganesh N. Pandian, S. Sato, J. Taniguchi, A. Chandran, K. Hashiya, T. Bando, H. Sugiyama, Targeted Suppression of EVI1 Oncogene Expression by Sequence-Specific PyrroleImidazole Polyamide, Chem. Biol., 21 (10) (2014) 1370-1380, doi: 10.1016/j.chembiol.2014.07.019.

[27] Y.-W. Han, G. Kashiwazaki, H. Morinaga, T. Matsumoto, K. Hashiya, T. Bando, Y. Harada, H. Sugiyama, Effect of single pyrrole replacement with $\beta$-alanine on DNA binding affinity and sequence specificity of hairpin pyrrole/imidazole polyamides 
targeting 5'-GCGC-3', Bioorg. Med. Chem., 21 (17) (2013) 54365441, doi: 10.1016/j.bmc.2013.06.005.

[28] A.N. Surovaya, G. Burckhardt, S.L. Grokhovsky, E. BirchHirschfeld, A.M. Nikitin, H. Fritzsche, C. Zimmer, G.V. Gursky, Binding of bis-linked netropsin derivatives in the parallel-stranded hairpin form to DNA, J. Biomol. Struct. Dyn., 18 (5) (2001) 689701, doi: 10.1080/07391102.2001.10506699.

[29] L. Halby, V.A. Ryabinin, A.N. Sinyakov, D.S. Novopashina, A.G. Venyaminova, S.L. Grokhovsky, A.N. Surovaya, G.V. Gursky, A.S. Boutorine, Head-to-head bis-hairpin polyamide minor groove binders and their conjugates with triplex-forming oligonucleotides: Studies of interaction with target doublestranded DNA, J. Biomol. Struct. Dyn., 25 (1) (2007) 61-76, doi: 10.1080/07391102.2007.10507156.

[30] A.E. Hargrove, J.A. Raskatov, J.L. Meier, D.C. Montgomery, P.B. Dervan, Characterization and Solubilization of PyrroleImidazole Polyamide Aggregates, J. Med. Chem., 55 (11) (2012) 5425-5432, doi: 10.1021/jm300380a.

[31] A.M. Bogdanov, E.I. Kudryavtseva, K.A. Lukyanov, Anti-fading media for live cell GFP imaging., PLoS ONE, 7 (12) (2012) e53004, doi: 10.1371/journal.pone.0053004.

[32] J. Ollion, F. Loll, J. Cochennec, T. Boudier, C. Escudé, Proliferation-dependent positioning of individual centromeres in the interphase nucleus of human lymphoblastoid cell lines, Mol. Biol. Cell, 26 (13) (2015) 2550-2560, doi: 10.1091/mbc.E14-051002.

[33] J. Ollion, Dynamique de l'organisation nucléaire des séquences d'ADN répétées centromériques humaines au cours du cycle cellulaire, Thèse de doctorat en Sciences de la vie $(\mathrm{PhD}$ Thesis in life sciences), http://www.theses.fr/2014PA066040 (2014), Paris 6 University, Paris.

[34] B. Vissel, K.H.A. Choo, Mouse major $(\gamma)$ satellite DNA is highly conserved and organized into extremely long tandem arrays: implications for recombination between nonhomologous chromosomes., Genomics, 5 (3) (1989) 407-414, doi: 10.1016/0888-7543(89)90003-7.

[35] C. Lee, R. Wevrick, B.R. Fisher, A.M. Ferguson-Smith, C.C. Lin, Human centromeric DNAs, Hum. Genet., 100 (3) (1997) 291-304, doi: $10.1007 / \mathrm{s} 004390050508$.

[36] Y. Kawamoto, T. Bando, F. Kamada, Y. Li, K. Hashiya, K. Maeshima, H. Sugiyama, Development of a New Method for Synthesis of Tandem Hairpin Pyrrole-Imidazole Polyamide Probes Targeting Human Telomeres, J. Am. Chem. Soc., 135 (44) (2013) 16468-16477, doi: 10.1021/ja406737n..

[37] Y. Kawamoto, A. Sasaki, A. Chandran, K. Hashiya, S. Ide, T. Bando, K. Maeshima, H. Sugiyama, Targeting 24 bp within Telomere Repeat Sequences with Tandem Tetramer PyrroleImidazole Polyamide Probes, J. Am. Chem. Soc., 138 (42) (2016) 14100-14107, doi: 10.1021/jacs.6b09023.

[38] P.R. Bohlander, H.-A. Wagenknecht, Synthesis and evaluation of cyanine-styryl dyes with enhanced photostability for fluorescent DNA staining, Org. Biomol. Chem., 11 (43) (2013) 7458-7462, doi: 10.1039/C3OB41717D.

[39] P.R. Bohländer, H.-A. Wagenknecht, Bright and photostable cyanine-styryl chromophores with green and red fluorescence colour for DNA staining, Meth. Appl. Fluoresc., 3 (4) (2015) 044003, doi:10.1088/2050-6120/3/4/044003.

[40] J. Shaya, F. Fontaine-Vive, B.Y. Michel, A. Burger, Rational Design of Push-Pull Fluorene Dyes: Synthesis and StructurePhotophysics Relationship, Chem. Eur. J., 22 (30) (2016) 1062710637, doi: 10.1002/chem.201600581.

[41] D. Dziuba, I.A. Karpenko, N.P.F. Barthes, B.Y. Michel, A.S. Klymchenko, R. Benhida, A.P. Demchenko, Y. Mély, A. Burger, Rational Design of a Solvatochromic Fluorescent Uracil Analogue with a Dual-Band Ratiometric Response Based on 3Hydroxychromone, Chem. Eur. J., 20 (7) (2014) 1998-2009, doi: 10.1002/chem.201303399. 